\title{
KEEFEKTIFAN PEMBELAJARAN KOOPERATIF TIPE TEAMS GAMES TOURNAMENT (TGT) BERBANTUAN MEDIA KAHOOT UNTUK TOPIK PERSAMAAN KUADRAT PADA SISWA KELAS X SMA IPH 2 SURABAYA
}

\author{
Alfa Charisma Sardjono Pello \\ Jurusan Pendidikan Matematika, Universitas Negeri Surabaya \\ albega127@yahoo.co.id
}

\begin{abstract}
This research was conducted in class X of IPH 2 High School Surabaya. Researcher looked at several problems in the classroom, namely: the ability of students to understand less quadratic equations, lack of learning tools that are good for use in classrooms, activities in class that seem unattractive to improve learning motivation and the condition of students who are always individual in achieving success. To support this, this research is assisted by kahoot media. This research is a type of experiment that begins with the development of a 4D model device. Based on the problems above, the researcher helps the teacher by developing learning tools that are well validated. After that, the researcher will check the effectiveness of the device and then be implemented in the experimental class in order to obtain good learning outcomes. Descriptive data analysis results, obtained valid learning tools, good teacher ability, positive student response, and student activities that are in a good range. The results of inferential data analysis obtained an average increase in learning outcomes in the experimental class is greater than the average increase in learning outcomes in the control class. Learning tools in the form of RPP, LKS, and THB developed with the 4-D development model are valid tools to support learning effectively so that student learning outcomes are better than student learning outcomes that are taught using conventional learning. Key Word: effectiveness, cooperative learning, teams games tournament, quadratic equations, kahoot media
\end{abstract}

\section{PENDAHULUAN}

Penelitian ini dilakukan di kelas X SMA IPH 2 Surabaya dikarenakan peneliti melihat beberapa masalah yang dihadapi siswa maupun guru dalam proses kegiatan belajar mengajar. Peneliti menemukan masalah seperti kemampuan siswa dalam memahami konsep persamaan kudrat yang masih kurang, tidak ada perangkat pembelajaran yang baik untuk digunakan oleh guru, besar kecenderungan siswa untuk bekerja secara individual, serta pembelajaran yang kurang kreatif sehingga tidak membuat siswa termotivasi. Peneliti melihat masalahmasalah di atas perlu diselesaikan segera karena akan memberikan efek yang negatif pada hasil belajar siswa ke depannya serta tidak kuatnya konsep yang harus dikuasai. Berdasarkan urgensi tersebut maka peneliti perlu menyiapkan pembelajaran yang mampu mengembangkan kemampuan siswa dalam menghadapi perkembangan jaman. Untuk menunjang hal tersebut maka peneliti perlu mengembangkan perangkat pembelajaran yang dapat memfasilitasi siswa di dalam kelas sehingga mempermudah guru dalam mengajar dan siswa dalam mengerjakan tugas nantinya. Pengembangan perangkat pembelajaran pada topik persamaan kuadrat dilakukan dengan model pengembangan 4D. Model Thiagarajan ini dipilih karena merupakan dasar untuk melakukan pengembangan perangkat pembelajaran (bukan sistem pembelajaran), tahap-tahap pelaksanaan dibagi secara detail dan sistematik(Thiagarajan, Semmel, \& Semmel, 1974). Oleh karena itu, perlu diadakannya pengembangan kurikulum yang memfasilitasi siswa dengan baik. Tujuan mengembangkan kurikulum dan pembelajaran adalah membantu siswa menghadapi tantangan pengetahuan, perubahan sosial, globalisasi, perkembangan teknologi dan persaingan ekonomi.(Herijanto, 2012)

Pendidikan harus mampu mengembangkan keterampilan bekerja sama (Santyasa, 2007). Keterampilan kerjasama dapat meningkatkan pencapaian hasil siswa, membangun hubungan yang positif antar siswa, menciptakan komunitas belajar yang beragam, menyediakan pengalaman yang membangun keterampilan belajar dan sosial yang baik(Alimuddin, 2014). Oleh karena itu, peneliti memilih metode pembelajaran kooperatif (cooperative learning) tipe teams 
games tournament (TGT) dengan alasan dapat meminimalisir sikap individual siswa dalam belajar di kelas. Slavin mengatakan bahwa apabila siswa menginginkan timnya berhasil, maka setiap anggota harus bekerja sama untuk mendorong anggota yang lain untuk melakukan usaha yang lebih baik lagi (Slavin, 1980)(R. T. Johnson \& Johnson, 1994).

Agar siswa dapat berusaha lebih baik lagi, maka peneliti melakukan pembelajaran dengan game berbasis online, yaitu kahoot(Ren \& Wagner, 2016). Media pembelajaran ini dapat memotivasi siswa untuk lebih bersemangat dalam belajar. Untuk menciptakan suasana belajar yang belajar yang sehat dan kompetitif, maka peneliti menggunakan salah satu fase TGT, yaitu fase turnamen untuk bersaing yang sehat, berkomunikasi, bersosialisasi dengan baik, selain itu dapat mengurangi individualis, serta meningkatkan hasil belajar(Lin, Ganapathy, \& Kaur, 2018).

Berdasarkan pengamatan, peneliti melihat bahwa konsep aljabar siswa kelas X SMA IPH 2 Surabaya tidak mencapai standar sekolah. Hal tersebut terlihat dari nilainilai yang telah diperoleh pada waktu UH. Salah satu UH aljabar yang menjadi fokus penelitian/ini adalah persamaan kuadrat. Dikarenakan lebih dari $70 \%$ dari jumlah siswa di kelas gagal dalam tugas maupun UH. Berdasarkan alasan inilah peneliti akan mengambil topik persamaan kuadrat.

Berdasarkan latar belakang di atas, maka peneliti melakukan penelitian dengan harapan dapat memberikan kontribusi yang berarti bagi pembelajaran di kelas $\mathrm{X}$ melalui penelitian berjudul pembelajaran kooperatif tipe Teams Games Tournament dengan media kahoot pada topik persamaan kuadrat untuk siswa kelas X SMA IPH 2 Surabaya. Penerapan pembelajaran kooperatif tipe TGT berbantuan media kahoot ini tidak hanya memberikan kesempatan bekerjasama dalam kelompok heterogen untuk membangun pemahaman, akan tetapi juga daya saing/ kompetisi yang sehat selama pembelajaran berlangsung (Salam, Hossain, \& Rahman, 2015).

\section{METODE PENELITIAN}

Penelitian ini dilakukan di kelas X SMA IPH 2 Surabaya dikarenakan peneliti melihat beberapa masalah yang dihadapi siswa maupun guru dalam proses kegiatan belajar mengajar. Peneliti menemukan masalah seperti kemampuan siswa dalam memahami konsep persamaan kudrat yang masih kurang, tidak ada perangkat pembelajaran yang baik untuk digunakan oleh guru, besar kecenderungan siswa untuk bekerja secara individual, serta pembelajaran yang kurang kreatif sehingga tidak membuat siswa termotivasi. Peneliti melihat masalahmasalah di atas perlu diselesaikan segera karena akan memberikan efek yang negatif pada hasil belajar siswa ke depannya serta tidak kuatnya konsep yang harus dikuasai. Berdasarkan urgensi tersebut maka peneliti perlu menyiapkan pembelajaran yang mampu mengembangkan kemampuan siswa dalam menghadapi perkembangan jaman (Learning \& Development, 1969). Untuk menunjang hal tersebut maka peneliti perlu mengembangkan perangkat pembelajaran yang dapat memfasilitasi siswa di dalam kelas sehingga mempermudah guru dalam mengajar dan siswa dalam mengerjakan tugas nantinya(Sari, Saputro, \& Hastuti, 2014). Pengembangan perangkat pembelajaran pada topik persamaan kuadrat dilakukan dengan model pengembangan 4D. Model Thiagarajan ini dipilih karena memiliki model yang lengkap dan memerlukan validasi untuk memperoleh perbaikan-perbaikan ke arah yang lebih baik(Thiagarajan et al., 1974). Oleh karena itu, perlu diadakannya pengembangan kurikulum yang memfasilitasi siswa dengan baik.

Menurut Alamudin Keterampilan kerjasama dapat meningkatkan pencapaian hasil siswa, membangun hubungan yang positif antar siswa, menciptakan komunitas belajar yang beragam, menyediakan pengalaman yang membangun keterampilan belajar dan sosial yang baik(Alimuddin, 2014). Oleh karena itu, peneliti memilih metode pembelajaran kooperatif (cooperative learning) tipe teams games tournament (TGT) dengan alasan dapat meminimalisir sikap individual siswa dalam belajar di kelas (Li \& Lam, 2013). 
Apabila siswa menginginkan timnya berhasil, maka setiap anggota harus bekerja sama untuk mendorong anggota yang lain untuk melakukan usaha yang lebih baik lagi (Slavin, 1980).

Agar siswa dapat berusaha lebih baik lagi, maka peneliti melakukan pembelajaran dengan game berbasis online, yaitu kahoot(Chaiyo \& Nokham, 2017). Media pembelajaran ini dapat memotivasi siswa untuk lebih bersemangat dalam belajar. Untuk menciptkana suasana belajar yang belajar yang sehat dan kompetitif, maka peneliti menggunakan salah satu fase TGT, yaitu fase turnamen untuk bersaing yang sehat, berkomunikasi, bersosialisasi dengan baik, selain itu dapat mengurangi individualis, serta meningkatkan hasil belajar(Chaiyo \& Nokham, 2017).

Berdasarkan pengamatan, peneliti melihat bahwa konsep aljabar siswa kelas X SMA IPH 2 Surabaya tidak mencapai standar sekolah. Hal tersebut terlihat dari nilainilai yang telah diperoleh pada waktu UH. Salah satu UH aljabar yang menjadi fokus penelitian ini adalah persamaan kuadrat. Dikarenakan lebih dari $70 \%$ dari jumlah siswa di kelas gagal dalam tugas maupun UH. Berdasarkan alasan inilah peneliti akan mengambil topik persamaan kuadrat.

Berdasarkan latar belakang di atas, maka peneliti melakukan penelitian dengan harapan dapat memberikan kontribusi yang berarti bagi pembelajaran di kelas $\mathrm{X}$ melalui penelitian berjudul pembelajaran kooperatif tipe Teams Games Tournament dengan media kahoot pada topik persamaan kuadrat untuk siswa kelas X SMA IPH 2 Surabaya. Penerapan pembelajaran kooperatif tipe TGT berbantuan media kahoot ini tidak hanya memberikan kesempatan bekerjasama dalam kelompok heterogen untuk membangun pemahaman, akan tetapi juga daya saing/ kompetisi yang sehat selama pembelajaran berlangsung.

Penelitian ini dapat digolongkan dalam jenis penelitian eksperimen (Campbell \& Stanley, 1967). Pada penelitian eksperimen ini akan dikembangkan perangkat pembelajaran(Thiagarajan et al., 1974). Berdasarkan pada pertanyaan penelitian pertama maka penelitian ini digolongkan ke dalam penelitian pengembangan. Sedangkan berdasarkan pertanyaan penelitian dua dan tiga maka penelitian ini termasuk penelitian eksperimen. Dalam penelitian eksperimen ini, terlebih dahulu akan dikembangkan perangkat pembelajaran. Perangkat pembelajaran yang dikembangkan adalah Rencana Pelaksanaan Pembelajaran (RPP), Lembar Kerja Siswa (LKS) dan Tes Hasil Belajar (THB) (Andrijati, Kurniawati, Masykuri, \& Saputro, 2016).

Penelitian ini di lakukan pada salah satu SMA swasta di surabaya, yaitu SMA IPH 2 Surabaya. Penelitian ini dilakukan dengan populasinya adalah seluruh siswa kelas X SMA IPH 2. Terdapat empat (4) kelas X sehingga peneliti memilih dua (3) kelas sebagai kelas eksperimen, kelas kontrol, dan kelas uji coba perangkat pembelajaran yang telah dikembangkan.

Terdapat beberapa instrumen yang dikumpulkan dalam penelitian ini untuk di analisis, yaitu: data hasil belajar siswa, data aktivitas siswa, data kemampuan guru mengelola pembelajaran, data respon siswa. cara pengambilan sampel dengan menggunakan metode Random Sampling(Sugiyono, 2014b).

Dalam penelitian ini akan terdapat dua macam prosedur yaitu: prosedur pengembangan dan prosedur eksperimen(Sugiyono, 2014b). Dalam pengembangan perangkat pembelajaran peneliti menggunakan model Thiagarajan 4D yang telah dimodifikasi, yaitu pada bagian desiminasi tidak dilakukan karena sampai pada tahap pengembangan karena telah ditemukan perangkat yang berkriteria baik. terdapat 3 (tiga) tahap dalam pengembangan yang dilakukan, yaitu pendefinisian, perancangan, dan pengembangan. Pada tahap pendefinisian peneliti menetapkan dan mendefinisikan kebutuhan-kebutuhan pembelajaran dan menganalisis tujuan dan batasan materi(Thiagarajan et al., 1974). Kegiatan yang dilakukan pada tahap pendefinisian adalah Analisis awal-akhir, analisis siswa, analisis materi, analisis tugas, spesifikasi tujuan dan indikator hasil belajar. Pada tahap perancangan peneliti merancang 
perangkat pembelajaran dengan strategi TGT yang berupa RPP, LKS dan THB sehingga diperoleh draf I yang sesuai dengan pembelajaran(Thiagarajan et al., 1974). kegiatan yang dilaksanakan adalah penyusunan tes acuan patokan, Pemilihan media, Pemilihan format, Perancangan awal perangkat. Pada tahap pengembangan peneliti menghasilkan draf perangkat pembelajaran yang telah direvisi berdasarkan masukan para ahli dan data yang diperoleh dari uji coba(Thiagarajan et al., 1974). Kegiatan yang dilakukan pada tahap ini adalah validasi perangkat pembelajaran, uji keterbacaan perangkat pembelajaran, uji coba perangkat pembelajaran.

Untuk analisis data hasil validasi perangkat, validator menuliskan penilaian pada setiap lembar validasi perangkat pembelajaran materi persamaan kuadrat yang terdiri dari RPP, LKS, dan THB. Perangkat pembelajaran dikatakan valid, jika setiap komponen perangkat pembelajaran mendapat kategori minimal cukup baik (nilai 3). Analisis data observasi terdiri dari kemampuan guru mengelola pembelajaran. Kemampuan guru mengelola pembelajaran baik, yakni jika semua komponen yang diamati berada pada kategori "baik" dan "sangat baik". Data aktivitas kelas dalam pembelajaran efektif, yakni jika presentase waktu terjadinya aktivitas berada pada selang presentase ideal yang ditetapkan dengan toleransi $10 \%$. Respon siswa terhadap perangkat pembelajaran positif, yakni jika komponen yang ditanyakan $80 \%$ siswa menanggapi positif. Data tes hasil belajar memenuhi kriteria valid, reliabel dan sensitif.

Untuk melihat perbedaan hasil belajar siswa yang menggunakan model pembelajaran kooperatif tipe TGT berbantuan media kahoot dan siswa yang menggunakan model konvensional, data pretes dan postes akan dianalisis dengan statistik inferensial analisis kovarian (anakova)(Putri, 2014). Analisis statistik anakova digunakan untuk menguji hipotesa dalam penelitian ini. Analisis kovarian (anakova) adalah penggabungkan antara uji komparatif dan korelasional atau dapat dikatakan anakova ini menguji perbandingan dan hubungan(Putri, 2014). Data yang akan dianalisis adalah hasil pretes sebagai variabel penyerta dan hasil postes sebagai variabel terikat. Sebelum anakova digunakan untuk menganalisis data, perlu diuji syarat berikut, model regresi antara variabel terikat $\mathrm{Y}$ (hasil belajar siswa) dan variabel penyerta $\mathrm{X}$ (kemampuan awal siswa) memenuhi hubungan linear sederhana dalam setiap kategori atau tingkat faktor yang diperhatikan. Dengan demikian, perlu ada pengaruh kemampuan awal (pretes) terhadap hasil belajar siswa untuk masing masing kelompok eksperimen dan kelompok kontrol (uji independensi), dan model regresi untuk masing-masing kelompok eksperimen dan kelompok kontrol harus linear (dengan uji linearitas regresi)(Sugiyono, 2014a).

\section{HASIL DAN PEMBAHASAN}

\section{Tahap Pengembangan}

Tahap pengembangan penelitian ini dibagi menjadi tiga tahap, yaitu tahap pendefinisian, tahap perancangan, tahap pengembangan(Thiagarajan et al., 1974).

\section{a. Tahap Pendefinisian}

Pertama, Pada tahap pendefinisian peneliti melakukan pengamatan dengan kegiatan antara lain mengadakan pertemuan dengan kepala sekolah IPH 2 Surabaya, wakil kurikulum IPH 2 Surabaya, dan guru mata pelajaran kelas X. Peneliti menemukan status sekolah sudah berubah ke SPK, kecenderungan penggunaan pembelajaran konvensional, yaitu menjelaskan konsep atau prosedur dengan sedikit interaksi dengan siswa, memberikan contoh soal, kemudian memberikan latihan soal.

Berdasarkan analisis di atas maka diperlukan alternatif pembelajaran yang berpusat pada siswa. Dengan mengkaji tuntutan era globalisasi yang bersifat kompetitif tanpa menghilangkan nilai-nilai gotong royong / kerjasama maka dipilihlah alternatif pembelajaran kooperatif tipe TGT berbantuan media kahoot(D. W. Johnson \& Johnson, 1999). Untuk melaksanakan pembelajaran kooperatif tipe TGT ini tentunya membutuhkan perangkat pembelajaran yang sesuai. Oleh karena perangkat pembelajaran disekolah belum memadai/ belum ada maka perlu dikembangkan suatu perangkat pembelajaran yang sesuai dan menunjang pelaksanaan pembelajaran. Perangkatperangkat pembelajaran yang dikembangkan adalah 
Rencana Pelaksanaan Pembelajaran (RPP), Lembar Kerja Siswa (LKS), Tes Hasil Belajar (THB)(Astuti, 2012).

Selain itu, peneliti juga memerlukan analisis siswa. Pada analisis siswa peneliti menelaah karakteristik siswa dalam hal latar belakang, tingkat kognitif, sosial budaya dan pengetahuan siswa. Siswa SMA IPH 2 Surabaya terdiri dari sebagian besar berasal dari keluarga keturunan Tionghoa bercampur Jawa dan rata-rata berumur 15-16 tahun. Dalam komunikasi sehari-hari siswa menggunakan budaya Jawa (dalam hal berbahasa). Ditinjau dari latar belakang pengetahuan siswa, mereka semua sudah pernah mengenal materi persamaan kuadrat pada waktu SMP kelas 9. Akan tetapi, cara-caranya sudah dilupakan. Berdasarkan hal tersebut, peneliti dapat menyimpulkan bahwa beberapa materi pada topik persamaan kuadrat belum diketahui siswa.

Siswa memiliki kecenderungan mengalami kesulitan dalam mengkomunikasikan ide atau konsep yang disebabkan oleh pembelajaran yang masih teacher centered (berpusat pada guru). Selain dari pada itu kecenderungan untuk tidak mau menghargai pendapat orang lain, susah menerima sebuah masukan, selalu berkompetisi untuk menunjukkan bahwa dirinyalah yang terbaik (egois), susah bertanggung jawab atas tugas yang diberikan. Peneliti memperoleh informasi bahwa siswa sudah pernah melakukan pembelajaran secara berkelompok pada mata pelajaran lain namun untuk pelajaran matematika siswa tidak pernah melakukan pembelajaran secara berkelompok yang didasarkan pembelajaran kooperatif tipe TGT berbantuan media kahoot. Sehingga peneliti menyimpulkan bahwa pembelajaran kooperatif tipe TGT berbantuan media kahoot adalah hal yang baru bagi mereka.

Berikutnya pada tahap pendefinisian memerlukan analisis materi dan spesifikasi tujuan untuk mempermudah dalam menyusun isntrumen pembelajaran. Berdasarkan pada hasil analisis materi, melalui analisis tugas untuk materi persamaan kuadrat diperoleh rumusan tugas sebagai berikut(Henseler, Fassott, Dijkstra, \& Wilson, 2012):
1) Menemukan pengertian persamaan kuadrat

2) Menghitung akar-akar persamaan kuadrat.

3) Rumus jumlah dan kali akar-akar Persamaan Kuadrat.

4) Disriminan dan jenis-jenis akar persamaan kuadrat.

Spesifikasi tujuan pembelajaran pada topik persamaan kuadrat ini dilakukan dengan menjabarkan kompetensi dasar ke dalam indikator yang lebih spesifik berdasarkan analisis konsep dan analisis tugas. Indikator yang lebih spesifik tersebut adalah(Yanti \& Syazali, 2016):

1) Siswa mampu menyimpulkan pengertian persamaan kuadrat.

2) Siswa mampu menentukan penyelesaian persamaan kuadrat dengan metode faktorisasi, kuadrat sempurna, rumus abc.

3) Siswa mampu menentukan jenis akar-akar persamaan kuadrat dengan menghitung diskriminan.

4) Siswa mampu menggunakan rumus $\mathrm{ABC}$ untuk menentukan hasil jumlah dan kali akar-akar persamaan kuadrat.

\section{b. Tahap Perancangan}

Pada tahap perancangan, peneliti melakukan pemilihan media, pemilihan format, dan rancangan awal.

Pada penelitian ini, media pembelajaran yang diperlukan oleh siswa adalah LKS (Lembar Kerja Siswa), THB (Tes Hasil Belajar). Media yang akan digunakan oleh guru adalah RPP (Rencana Pelaksanaan Pembelajaran) dan Media Kahoot yang akan digunakan pada tahapan turnamen pembelajaran kooperatif tipe TGT. Sedangkan alat bantu pelajaran yang diperlukan meliputi: papan tulis, spidol, penghapus, buku tulis, pulpen, penggaris, LCD dan proyektor.

Format Rencana Pelaksanaan Pembelajaran (RPP) yang digunakan disesuaikan dengan format RPP dalam KTSP 2006 serta prinsip dan langkah-langkah dalam pembelajaran kooperatif tipe TGT berbantuan media kahoot. Isi pembelajaran mengacu pada hasil analisis materi, hasil analisis tugas, spesifikasi tujuan dan indikator hasil belajar yang dirumuskan pada tahap 
pendefinisian. Secara garis besar dapat diuraikan sebagai berikut:

1) Dalam RPP tercantum judul, satuan pendidikan, mata pelajaran, kelas/ semester, materi, alokasi waktu, standar kompetensi, kompetensi dasar, indikator, materi pembelajaran, dan kegiatan pembelajaran yang dilakukan oleh guru dan siswa dalam tahapan pembelajaran kooperatif tipe TGT berbantuan media kahoot sera rincian alokasi waktunya.

2) Format LKS dibuat sejelas mungkin agar siswa mampu memahami perintah dan mampu termotivasi untuk mengerjakan soal-soal tersebut dengan baik.

Format THB tercantum judul, satuan pendidikan, mata pelajaram, kelas/semester, materi, alokasi, petunjuk, dan soal tes. Format tes hasil belajar juga dibuat sedemikian rupa sehingga siswa mampu memotivasi siswa dalam menjawab setiap pertanyaan.

Pada tahap ini dihasilkan rancangan awal rencana pembelajaran untuk empat kali pertemuan, lembar kerja siswa yang di dalamnya terdapat kegiatan siswa pada setiap pertemuan, soal dan jawaban untuk tes hasil belajar siswa. Hasil ini akan disebut sebagai draf awal/ I:

a. Rencana Pelaksanaan Pembelajaran

\section{Rencana Pelaksanaan Pembelajaran yang} dikembangkan sebanyak empat buah untuk empat kali pertemuan. Pertemuan I dengan waktu 2 x 50 menit dan materi pengertian persamaan kuadrat dan menentukan akar-akar persamaan kuadrat. Pada pertemuan II dengan waktu 2 x 50 menit dengan materi menentukan akar-akar persamaan kuadrat. Pertemuan III dengan waktu 2 x 50 menit dengan materi menentukan jenis akar-akar persamaan kuadrat berdasarkan nilai diksirminan. Pertemuan IV dengan waktu 2 x 50 menit dengan materi menentukan rumus hasil jumlah dan kali akar-akar persamaan kuadrat.

\section{b. Lembar Kerja Siswa}

penyusunan LKS ini mempermudah pemahaman terhadap materi yang diberikan dan bertujuan mengembangkan kompetensi siswa. Lembar Kerja Siswa ini memberi penekanan pada proses untuk menemukan konsep-konsep sehingga LKS dapat berfungsi sebagai petunjuk untuk mengkonstruk pengetahuan siswa. LKS ini terdapat bagian untuk soal/ masalah dan bagian untuk jawaban sehingga siswa dapat menuliskan pada tempat yang diberikan serta dibuat pada setiap kali guru melakukan tatap muka.

\section{c. Tes Hasil Belajar}

Tes hasil belajar merupakan salah satu perangkat yang dikembangkan untuk mengukur hasil belajar siswa. Bentuk Tes yang digunakan adalah bentuk uraian. Penyusunan tes hasil belajar disesuaikan dengan hasil belaajr yang lebih spesifik, seperti yang telah diuraikan terdahulu. Tes yang diberikan kepada siswa ini hanya mengukur sebatas kognitif saja. Tes Hasil belajar ini terdiri atas 6 butir soal. Waktu yang disediakan untuk menyelesaikan semua soal tersebut adalah 95 menit dan 5 menit untuk mengumpulkan soal. Penyusunan tes ini mencakup: perancangan kisi-kisi, penyusunan butir soal, dan kunci jawaban.

\section{c. Tahap Pengembangan}

Pada tahap pengembangan akan dilakukan validasi ahli, uji keterbacaan, uji coba perangkat (Thiagarajan et al., 1974).

Validasi ahli dilakukan untuk melihat dan memeriksa validitas isi, bahasa dari semua dokumen yang dikembangkan. Hasil validasi para ahli digunakan untuk melakukan revisi dan penyempurnaan terhadap perangkat pembelajaran. Perangkat pembelajaran hasil revisi berdasarkan masukan para ahli ini selanjutnya diujicobakan.

Tabel 1. Hasil Penilaian Validator pada Perangkat

\begin{tabular}{|c|c|c|c|c|c|c|}
\hline \multirow{2}{*}{ No } & \multirow{2}{*}{ Perangkat } & \multicolumn{3}{|c|}{ Nilai yang diberikan validator } & \multirow{3}{*}{$\begin{array}{c}\text { Rata rata } \\
4.14\end{array}$} & \multirow{2}{*}{ Kategori } \\
\hline & & I & II & III & & \\
\hline 1 & RPP & 4.29 & 4.10 & 4.02 & & Baik \\
\hline 2 & LKS & 4.04 & 4.02 & 4.12 & 4.06 & Baik \\
\hline
\end{tabular}




\begin{tabular}{|c|c|c|c|c|c|c|}
\hline \multirow{2}{*}{ No } & \multirow{2}{*}{ Perangkat } & \multicolumn{2}{|c|}{ Nilai yang diberikan validator } & \multirow{2}{*}{ Kategori } \\
\cline { 3 - 6 } & & I & II & III & Rata rata & V \\
\hline 3 & THB & V & V & V & V & Valid \\
\hline
\end{tabular}

Sekalipun perangkat pembelajaran yang dipersiapkan oleh peneliti dinyatakan valid dan baik, namun terdapat beberapa pendapat serta saran penting dari validator yang mendorong perlu dilakukan revisi terhadap dokumen perangkat pembelajaran.

Uji keterbacaan ini dilakukan dengan cara memberikan draf II yaitu LKS kepada 4 subjek uji keterbacaan yang terdiri dari 1 siswa berkemampuan rendah, 1 siswa berkemampuan sedang, 1 siswa berkemampuan tinggi, dan 1 guru mata pelajaran. Pada uji keterbacaan ini siswa diminta untuk menggarisbawahi kata-kata atau kalimat yang tidak dimengerti.

Pelaksanaan ujicoba ini diperlukan waktu 6 hari dimana 4 hari pelaksanaan pembelajaran, 1 hari pelaksanaan pretes dan 1 hari pelaksanaan postes. Berdasarkan hasil pengamatan kemampuan guru mengelola pembelajaran matematika dengan pembelajaran kooperatif tipe TGT berbantuan media kahoot untuk materi persamaan kuadrat dapat terlihat bahwa skor rata rata setiap aspek di setiap RPP yaitu 4.0 yang berarti nilai ini menunjukan keterangan baik sehingga memenuhi kriteria yang telah ditetapkan. Dengan demikian, perangkat pembelajaran bisa dikatakan praktis dan tidak perlu lagi dilakukan revisi.

Pengamatan terhadap aktivitas siswa selama kegiatan pembelajaran menggunakan lembar observasi aktivtas siswa. Aktivitas siswa diamati oleh seorang pengamat. Pada penelitian ini, pengamat mengamati 4 siswa yang dilakukan sejak mulai pembelajaran sampai akhir pembelajaran. Dapat terlihat bahwa setiap rata-rata pada aspek yang direspon berada pada kriteria waktu ideal. Dengan demikian, ditinjau dari kriteria waktu ideal aktivitas siswa maka dapat disimpulkan bahwa pembelajaran memenuhi kriteria efektif.

Berdasarkan angket respon siswa yang telah diisi oleh 16 siswa yang mengikuti pembelajaran kooperatif tipe
TGT berbantuan media kahoot untuk materi persamaan kuadrat. respon terhadap komponen pembelajaran matematika dengan pembelajaran kooperatif tipe TGT berbantuan media kahoot dapat disimpulkan positif. Selain itu, siswa memiliki minat yang tinggi untuk mengikuti pembelajaran matematika berikutnya dengan menggunakan pembelajaran kooperatif tipe TGT berbantuan media kahoot. Dengan demikian, berdasarkan hasil respon siswa yang bernilai positif (lebih dari 80\%), maka perangkat tersebut tidak perlu direvisi.

Pada tes hasil belajar akan dilakukan pertama, perhitungan validitas setiap butir soal dengan menggunakan rumus korelasi product moment. Berdasarkan perhitungan dengan product moment maka dapat disimpulkan bahwa secara umum validitas tiap butir soal tes hasil belajar adalah valid dan dapat digunakan tanpa revisi karena kriteria tiap butir soal berada pada kriteria tinggi dan cukup tinggi. Kedua, Berdasarkan hasil perhitungan reliabilitas tes hasil belajar, diperoleh koefisien reliabilitas $\alpha=0.740$ Artinya reliabilitas tes hasil belajar tinggi. Selain itu, bedasarkan koefisien tersebut maka setiap butir soal dapat digunakan tanpa perlu direvisi lagi untuk mengukur tingkat penguasaan siswa terhadap materi persamaan kuadrat. Ketiga, Berdasarkan perhitungan sensitifitas butir soal maka dapat dikatakan bahwa setiap butir soal sensitif terhadap pembelajaran. Oleh karena itu, setiap butir soal tes hasil belajar dapat dikatakan layak untuk digunakan tanpa adanya revisi.

Bedasarkan pengembangan perangkat dengan menggunakan model 4-D, dihasilkan perangkat pembelajaran kooperatif tipe TGT berbantuan media kahoot. Adapun perangkat pembelajaran tersebut terdiri atas RPP, LKS, THB yang dapat dilihat pada lampiran. Sedangkan instrument penelitian yang meliputi lembar observasi kemampuan guru mengelola pembelajaran, 
Alfa Charisma Sardjono Pello: Keefektifan Pembelajaran Kooperatif Tipe Teams Games Tournament (TGT)

Berbantuan Media Kahoot Untuk Topik Persamaan Kuadrat Pada Siswa Kelas X SMA IPH 2 Surabaya

lembar observasi aktivitas siswa, dan angket respon siswa sudah bisa digunakan untuk eksperimen.

\section{Tahap Eksperimen}

Pada tahap eksperimen, peneliti ingin memberikan hasil penelitian dalam dua bentuk yaitu deskriptif dan inferensial. Pada analisis desktiptif peneliti ingin mengetahui kemampuan guru mengelola pembelajaran, aktivitas siswa, respon siswa, gambaran tes hasil belajar. Sedangkan untuk analisis inferensial peneliti menggunakan data hasil postes dan pretes (Kirk, 2013).

\section{a. Analisis Deskriptif}

Hasil penelitian penerapan perangkat yang telah diimplementasikan ini adalah data yang dianalisis secara deskriptif. Data tersebut diantaranya adalah kemampuan guru mengelola pembelajaran, data aktivitas siswa terhadap pembelajaran kooperatif tipe TGT berbantuan media kahoot, serta data hasil belajar siswa

Pada proses pembelajaran di kelas eskperimen untuk setiap pertemuannya terlihat bahwa secara umum pada setiap pertemuan yaitu sebanyak 4 kali, kemampuan guru dalam mengajar di kelas berada pada kriteria baik. Hal tersebut berarti kemampuan guru dalam/mengelola pembelajaran kooperatif tipe TGT berbantuan media kahoot untuk materi persamaan kuadrat di kelas X SMA IPH 2 Surabaya adalah baik.

Berdasarkan hasil penerapan hasil pengembangan perangkat pembelajaran maka dapat terlihat bahwa ratarata aspek yang direspon pada setiap pertemuan berada pada kriteria waktu ideal. Dengan demikian, jika ditinjau dari waktu ideal aktivitas sisa maka dapat disimpulkan bahwa selama proses pembelajaran di kelas eksperimen memenuhi kriteria efektif.

Berdasarkan angket respon siswa pada penelitian di kelas eksperimen ini, maka diperoleh 16 respon siswa yang mengikuti proses pembelajaran dengan model pembelajaran kooperatif tipe TGT berbantuan media kahoot. respon siswa terhadap komponen pembelajaran kooperatif tipe TGT berbantuan media kahoot dapat disimpulkan berada pada nilai positif. Hal ini dikarenakan bernilai lebih dari $80 \%$, yaitu $87,5 \%$.
Tes Hasil Belajar di analisis dengan menggunakan validitas, reliabilitas, sensitifitas. Pertama, perhitungan validitas setiap butir soal dengan menggunakan rumus korelasi product moment. Berdasarkan hasil analisis validitas, maka dapat disimpulkan bahwa secara umum validitas tiap butir soal tes hasil belajar adalah valid dan dapat digunakan tanpa revisi karena kriteria tiap butir soal berada pada kriteria tinggi dan cukup tinggi. Kedua, Berdasarkan hasil perhitungan tes hasil belajar, diperoleh koefisien reliabilitas $\alpha=0.702$ artinya reliabilitas tes hasil belajar tinggi. Selaiun itu berdasarkan koefisien tersebut maka setiap butir soal dapat digunakan tanpa perlu revisi lagi untuk mengukur tingkat penguasaan siswa terhadap materi persamaan kuadrat. Ketiga, berdasarkan perhitungan sensitiftas setiap butir soal maka dapat disimpulkan bahwa setiap butir soal sensitive terhadap pembelajaran. Oleh karena itu, setiap butir soal tes hasil belajar dapat dikatakan layak untuk digunakan tanpa adanya revisi.

Ketuntasan untuk belajar siswa secara klasikal pada kelas eksperimen tergolong tuntas. Hal tersebut dikarenakan ketuntasan belajar yang diperoleh lebih dari 85\%. Berdasarkan analisis deskriptif pada data kelas eksperimen ini, maka diperoleh kesimpulan bahwa model pembelajaran kooperatif tipe TGT berbantuan media kahoot untuk materi persamaan kuadrat ini efektif digunakan. Hal tersebut dikarenakan telah memenuhi beberapa kriteria kemampuan guru dalam mengelola pembelajaran berkriteria baik, aktifitas siswa selama pembelajaran efektif, respon siswa positif, hasil belajar siswa secara klasikal tuntas.

\section{b. Analisis Inferensial}

Analisis statistik inferensial ini digunakan untuk menganalisis tes hasil belajar siswa (THB). Analisis ini bertujuan untuk menguji hipotesis yang diajukan sekaligus untuk menjawab pertanyaan penelitian yang ketiga. Perlu diketahui bahwa variabel kovariat pada penelitian ini adalah kemampuan awal siswa yang diperoleh dari nilai hasil pretes sedangkan variabel terikat adalah hasil belajar siswa yang diperoleh dari postes. Data 
tes hasil belajar siswa ini dianalisis menggunakan analisis kovariat (Anakova) dan diperoleh model regresi kedua kelas adalah: model regresi kelas eksperimen diperoleh model regresi sebagai berikut:

$$
Y_{E}=76.116+1.225 X_{E}
$$

Sedangkan untuk kelas kontrol diperoleh model regresi sebagai berikut:

$$
Y_{K}=63.48+0.773 X_{K}
$$

Berdasarkan hasil perhitungan regresi maka dapat disimpulkan bahwa model regresi dari kelas eskperimen lebih baik dari kelas control.

Analisis independensi model regresi kelas eksperimen dengan menggunakan taraf signifikan $\alpha=0.05$ diperoleh $\quad F_{(0.95,1,14)}=4.60 \quad$ berarti $F^{*} \geq F_{(0.95,1,14)}$ Sehingga Ho ditolak. Berarti kemampuan awal siswa $(\mathrm{X})$ mempunyai pengaruh yang signifikan terhadap hasil belajar siswa (Y). Sedangkan, Analisis independensi model regresi kelas kontrol dengan menggunakan taraf signifikan $\alpha=0.05$ diperoleh $F_{(0.95,1,14)}=4.60$ berarti $\mathrm{F}^{*}<F_{(0.95,1,14)}$

Sehingga Ho diterima. Berarti kemampuan awal siswa (X) tidak mempunyai pengaruh yang signifikan terhadap hasil belajar siswa (Y). Hal ini berarti analisis kovarian tidak bisa dilanjutkan. Sehingga untuk berikutnya akan digunakan uji mean dua populasi peningkatan hasil belajar.

Analisis deskriptif peningkatan hasil Belajar untuk kelas eksperimen dan kelas kontrol menggunakan rumus mean dan varians. Sehingga diperoleh mean dan varians kelas eksperimen adalah:

- $\quad$ Mean D $\left(\overline{D_{1}}\right)=\frac{\sum D_{1}}{n 1}=\frac{1250}{16}=78.125$

- Varians D

(

$\left.S_{1}^{2}\right)=\frac{\left(n 1 \times \sum D_{1}^{2}\right)-\sum D_{1}}{n(n-1)}=\frac{(16 \times 98301)-1250}{16 \times 15}=$ 43.00
Sedangkan mean dan varian kelas kontrol adalah:

- $\quad \operatorname{Mean} \mathrm{D}\left(\overline{D_{2}}\right)=\frac{\sum D_{2}}{n_{2}}=\frac{987.2}{16}=61.7$

- Varians D

(

$\left.S_{2}^{2}\right)=\frac{\left(n_{2} \times \sum D_{2}^{2}\right)-\sum D_{2}}{n_{2}\left(n_{2}-1\right)}=\frac{(16 \times 61297)-987.2}{16 \times 15}=$

25.5

Berdasarkan perhitungan di atas maka dapat disimpulkan bahwa rata-rata dan varians dari kelas eksperimen lebih besar dari mean dan varian dari kelas kontrol.

Langkah pertama sebelum dilakukan uji mean dua populasi maka dilakukan uji kesamaan varians, yaitu:

a. Ho : $\sigma_{1}^{2}=\sigma_{2}^{2}$

b. $\mathrm{H} 1: \sigma_{1}^{2} \neq \sigma_{2}{ }^{2}$

c. $\alpha=0.05$

d. Kriteria penolakan Ho: Tolak Ho jika $F=\frac{s_{1}^{2}}{s_{2}^{2}}>F(0.05: 15: 15)=2.4$

e. Menghitung Nilai $F$

$$
F=\frac{S_{1}^{2}}{S_{2}^{2}}=\frac{43}{25.5}=1.686
$$

Karena

$F_{\text {hitung }}=1.686<2.4 F_{\text {tabel }}(0.05: 15: 15)$

maka Ho diterima dengan kata lain varian kedua populasi bernilai sama sehingga untuk menguji mean kedua

populasi digunakan statistik $t=\frac{\left(D_{1}-\bar{D}_{2}\right)-\mu_{0}}{S_{p} \cdot \sqrt{\frac{1}{n 1}+\frac{1}{n 2}}}$, dengan

$$
S_{p}^{2}=\frac{\left(n_{1}-1\right) \cdot S_{1}^{2}+\left(n_{2}-1\right) \cdot S_{2}^{2}}{n_{1+n_{2}-2}}
$$

Langkah kedua untuk menentukan kesamaan dan perbedaan mean dua populasi, yaitu:
a. $\quad$ Ho $: \mu_{1}=\mu_{2}$
b. $\mathrm{H} 1: \mu_{1}>\mu_{2}$
c. $\alpha=0.05$ 
Alfa Charisma Sardjono Pello: Keefektifan Pembelajaran Kooperatif Tipe Teams Games Tournament (TGT)

Berbantuan Media Kahoot Untuk Topik Persamaan Kuadrat Pada Siswa Kelas X SMA IPH 2 Surabaya

d. Kriteria penolakan Ho :

Tolak Ho jika

$$
t=\frac{\left(\overline{D_{1}}-\overline{D_{2}}\right)-\mu_{0}}{s_{p} \sqrt{\frac{1}{n_{1}}+\frac{1}{n^{2}}}}>t(0.05 ; 30)=1.697
$$

e. Menghitung nilai statistik $\mathrm{t}$ persamaan kuadrat di kelas $\mathrm{X}$ dengan mengikuti model pengembangan 4-D yang dimodifikasi adalah perangkat yang baik/ valid. Tahapan pengembangan perangkat yang dimodifikasi meliputi, tahap pendefinisian (define), perancangan (design), dan pengembangan (develop).

$S_{p}^{2}=\frac{\left(n_{1}-1\right) \cdot S_{1}^{2}+\left(n_{2}-1\right) \cdot S_{2}^{2}}{n_{1+n_{2}-2}}=\frac{(15 \times 43)+(15 \text { Perangkat })}{30 \text { Pelaksanaan }}=34.755^{5}$ lajaran (RPP), Lembar kerja Siswa $S_{p}=\sqrt{34.25}=5.85$ (LKS), Tes Hasil Belajar (THB).

Pembelajaran Kooperatif tipe TGT berbantuan media Sehingga nilai $t$ adalah :

$$
t=\frac{\left(\overline{D_{1}}-\overline{D_{2}}\right)-\mu_{0}}{S_{p^{*}} \sqrt{\frac{1}{n 1}+\frac{1}{n 2}}}=\frac{(78.125-61.7)-0}{5.85\left(\sqrt{\frac{1}{8}}\right)}=7.94
$$
kahoot efektif untuk mengajarkan materi persamaan kuadrat. Hal ini dibuktikan dengan hasil pengamatan

$$
\text { f. Karena } t=7.94>1.697=t_{(0.05: 30)} \text {, maka }
$$

Ho ditolak dan $\mathrm{H} 1$ diterima. Hal ini berarti rata-rata peningkatan hasil belajar dikelas eksperimen lebih besar daripada rata-rata peningkatan hasil belajar di kelas kontrol.

Sehingga dapat disimpulkan bahwa Untuk $\mu_{0}=12$ diperoleh :

$$
\begin{aligned}
& t=\frac{\left(\overline{D_{1}}-\overline{D_{2}}\right)-\mu_{0}}{S_{p^{*}} \sqrt{\frac{1}{n 1}+\frac{1}{n 2}}} \\
& =\frac{(78.125-61.7)-12}{5.85\left(\sqrt{\frac{1}{8}}\right)}=2.139
\end{aligned}
$$

Yang mana $t=2.139>1.697=t(0.05: 30)$

Hal ini berarti secara populatif, rata-rata peningkatan hasil belajar di kelas eksperimen melebihi lebih 12 poin dari pada rata-rata peningkatan hasil belajar di kelas kontrol.

\section{PENUTUP}

\section{Simpulan}

Berdasarkan hasil penelitian, maka disimpulkan bahwa Perangkat pembelajaran berupa Rencana Pembelajaran, Lembar Kerja Siswa, dan Tes Hasil Belajar yang peneliti buat dan kembangkan untuk mengajarkan materi terhadap pelaksanaan pembelajaran dengan menggunakan perangkat pembelajaran yang baik/ valid dengan indikator ketercapaian berupa ketercapaian ketuntasan belajar siswa secara klasikal, aktivitas siswa efektif, kemampuan guru mengelola pembelajaran efektif, serta respon siswa terhadap pembelajaran kooperatif tipe TGT berbantuan media kahoot positif.

Hasil belajar siswa yang diajar dengan menggunakan pembelajaran kooperatif tipe TGT berbantuan media kahoot untuk materi persamaan kuadrat di kelas X lebih baik dari hasil belajar siswa yang diajarkan dengan menggunakan pembelajaran konvensional.

Perangkat pembelajaran yang telah peneliti kembangkan dapat digunakan sebagai alternatif untuk mengajarkan materi persamaan kuadrat di kelas X karena berdasarkan uji coba, perangkat yang dikembangkan dapat mengaktifkan siswa dalam pembelajaran dan dapat digunakan guru untuk mengelola pembelajaran serta mendapat respon positif dari siswa.

\section{DAFTAR PUSTAKA}

Alimuddin. (2014). Penilaian dalam kurikulum 2013. Seminar NAsional Pendidikan Karakter.

Andrijati, N., Kurniawati, D., Masykuri, M., \& Saputro, S. (2016). Pengembangan Perangkat Pembelajaran. Jurnal Pendidikan Kimia (JPK). https://doi.org/pISSN:2089-5003

Astuti, M. S. Y. (2012). Pengembangan Perangkat 
Pembelajaran Matematika Realistik Dalam Upaya Meningkatkan Prestasi Belajar Matematika Siswa Sekolah Dasar Di Kecamatan Rendang. Jurnal Ilmiah Pendidikan Dan Pembelajaran.

Campbell, D. T., \& Stanley, J. C. (1967). Experimental and Quasi-Experimental Design for Research. Handbook of Research on Teaching (1963). https://doi.org/10.1037/022808

Chaiyo, Y., \& Nokham, R. (2017). The effect of Kahoot, Quizizz and Google Forms on the student's perception in the classrooms response system. In 2nd Joint International Conference on Digital Arts, Media and Technology 2017: Digital Economy for Sustainable Growth, ICDAMT 2017. https://doi.org/10.1109/ICDAMT.2017.7904957

Henseler, J., Fassott, G., Dijkstra, T. K., \& Wilson, B. (2012). Analysing quadratic effects of formative constructs by means of variance-based structural equation modelling. European Journal of Information Systems. https://doi.org/10.1057/ejis.2011.36

Herijanto, B. (2012). Pengembangan CD Interaktif Pembelajaran IPS Materi Bencana Alam. Journal of Educational Social Studies. https://doi.org/10.15294/jess.v1i1.73

Johnson, D. W., \& Johnson, R. T. (1999). Making cooperative learning work. Theory Into Practice. https://doi.org/10.1080/00405849909543834

Johnson, R. T., \& Johnson, D. W. (1994). An overview of cooperative learning. Creativity and Collaborative Learning: A Practical Guide to Empowering Students and Teachers. https://doi.org/10.1007/BF00962280

Kirk, R. E. (2013). Experimental design. Handbook of Psychology, Vol. 2: Research Methods in Psychology (2nd $E d$.). https://doi.org/10.4135/9780857020994
Learning, C. F. O. R., \& Development, P. (1969). Student-centred Learning. Learning.

Li, M. P., \& Lam, B. H. (2013). Cooperative Learning. The Hong Kong Institute of Education.

Lin, D. T. A., Ganapathy, M., \& Kaur, M. (2018). Kahoot! It: Gamification in higher education. Pertanika Journal of Social Sciences and Humanities.

Putri, F. E. N. (2014). Perbedaan Hasil Belajar Ditinjau dari Pembelajaran Kooperatif , Perilaku Berkarakter dan Disposisi Matematis. JURNAL PENDIDIKAN MATEMATIKA.

Ren, C., \& Wagner, J. (2016). Kahoot! TESL-EJ.

Salam, A., Hossain, A., \& Rahman, S. (2015). Effects of Using Teams Games Tournaments (TGT) Cooperative Technique for Learning Mathematics in Secondary Schools of Bangladesh. Malaysian Online Journal of Educational Technology. https://doi.org/10.4471/redimat.2015.1519

Santyasa, I. W. (2007). Model-Model Pembelajaran Inovatif. Makalah.

Sari, K. W., Saputro, S., \& Hastuti, D. B. (2014). Pengembangan Game Edukasi Kimia Berbasis Role Playing Game (Rpg) pada Materi Struktur Atom sebagai Media Pembelajaran Mandiri untuk Siswa Kelas X Sma di Kabupaten Purworejo. Jurnal Pendidikan Kimia (JPK).

Slavin, R. E. (1980). Cooperative Learning. Review of Educational

Research. https://doi.org/10.3102/00346543050002315

Sugiyono. (2014a). Desain Penelitian. Metode Penelitian Kuantitatif, Kualitatif Dan R\&D.

Sugiyono. (2014b). Metode Penelitian Kuantitatif, Kualitatif dan $R$ \& D. Bandung: Alfabeta. https://doi.org/10.1017/CBO9781107415324.004

Thiagarajan, S., Semmel, D. S., \& Semmel, M. I. (1974). 
Alfa Charisma Sardjono Pello: Keefektifan Pembelajaran Kooperatif Tipe Teams Games Tournament (TGT)

Berbantuan Media Kahoot Untuk Topik Persamaan Kuadrat Pada Siswa Kelas X SMA IPH 2 Surabaya

Instructional Development for Training Teachers

of Exceptional Children: A Sourcebook. ERIC.

Yanti, A. P., \& Syazali, M. (2016). Analisis Proses Berpikir Siswa Dalam Memecahkan Masalah Matematika Berdasarkan Langkah-Langkah Bransford Dan Stein Ditinjau Dari Adversity Quotientsiswa Kelas X Man 1 Bandar Lampung Tahun. Al-Jabar. https://doi.org/10.13541/j.cnki.chinade.2012.10.00 4 